\title{
Specimen Adequacy and Clinicopathological Evaluation of Inflammatory Bowel Disease Colorectal Biopsies in Cipto Mangunkusumo Hospital Jakarta
}

\author{
Lydia Kencana, Nur Rahadiani, Marini Stephanie, Diah Rini Handjari, \\ Ening Krisnuhoni \\ Department of Anatomical Pathology, Faculty of Medicine Universitas Indonesia/ \\ Dr. Cipto Mangunkusumo General National Hospital, Jakarta
}

\section{Corresponding author:}

Nur Rahadiani. Department of Anatomical Pathology, Dr. Cipto Mangunkusumo National General Hospital. Jl Diponegoro No.71 Jakarta Indonesia.Phone/facsimile: E-mail:nur.rahadiani@ui.ac.id

\begin{abstract}
Background: Colorectal mucosal biopsies account for majority of daily practice specimens in the field of gastrointestinal pathology. Most of them were sent for inflammatory bowel disease (IBD) evaluation. Due to broad spectrum of histologic findings and different stage of disease, pathologists often find difficulties on calling out diagnosis of IBD. This study aims to evaluate the adequacy of specimen, clinical characteristics, endoscopy and histologic findings of colorectal biopsies from IBD and non-IBD patients.

Method: This cross-sectional study included 49 IBD and 49 non-IBD cases registered in the archives of Anatomical Pathology Department, Cipto Mangunkusumo National Referral Hospital Jakarta in 2019. The samples were evaluated for adequacy of specimen, clinical, endoscopy and histologic findings.

Results: Most samples were adult with a slight female predominance. All request forms contained the clinical working diagnosis but only $26.5 \%$ and $20.4 \%$ of them provided clinical history and endoscopy findings. During histology evaluation, $59.2 \%$ of the specimen was considered sub-optimal. The most common histologic findings in both IBD and non-IBD groups were diffuse lymphoplasmacytic infiltration in the lamina propria and crypt distortion. Fibrosis/collagen deposition was found in $38.8 \%$ of IBD population compared to $12.2 \%$ of non-IBD population ( $p=0.003)$. Most IBD cases (55.1\%) were categorized as active phase IBD.

Conclusion: Since the most common histologic findings in IBD patients were also found in non-IBD patients, IBD diagnosis based on histopathology alone is highly inadvisable. However, there were also lack of clinical data and endoscopy findings in most of colorectal biopsies sent for IBD evaluation. Along with overlapping and unspecific morphology and suboptimal events during histological evaluation, all of this complicated the diagnosis of IBD. Hence multidisciplinary approach is required for a better IBD diagnosis and treatment.
\end{abstract}

Keywords: Inflammatory bowel disease, colorectal biopsy, specimen adequacy.

\section{ABSTRAK}

Latar belakang: Biopsi kolorektal merupakan kasus yang banyak dijumpai pada praktek sehari-hari di bidang patologi gastrointestinal. Sebagian besar spesimen dikirim untuk evaluasi inflammatory bowel disease (IBD). Namun, gambaran IBD yang beragam serta adanya variasi derajat penyakit menyebabkan sulitnya penentuan diagnosis IBD secara patologi. Penelitian ini bertujuan untuk evaluasi adekuasi spesimen, temuan klinis, endoskopi, dan histologi pada biopsi kolorektal pada pasien IBD dan non-IBD. 
Metode: Penelitian ini merupakan studi potong lintang dengan 49 sampel IBD dan 49 sampel non-IBD yang diperoleh dari arsip Departemen Patologi Anatomik RSUPN Cipto Mangunkusumo Jakarta pada 2019. Dilakukan analisis terhadap adekuasi spesimen, temuan klinis, endoskopi, dan histologi.

Hasil: Sebagian besar sampel berusia dewasa dengan jenis kelamin perempuan sedikit lebih banyak dibanding laki-laki. Seluruh formulir permintaan histopatologi memuat diagnosis klinis namun hanya 26.5\% dan 20,4\% memuat informasi mengenai riwayat penyakit dan temuan endoskopi. Gambaran histologi tersering pada kelompok IBD dan non-IBD adalah sebukan limfoplasmasitik difus pada lamina propria dan distorsi kripta. Fibrosis/deposisi kolagen ditemukan pada 38,8\% kasus IBD, dibandingkan dengan 12,2\% kasus non-IBD $(p=0,003)$. Sebagian besar kasus IBD $(55,1 \%)$ didiagnosis sebagai IBD fase aktif.

Simpulan: Temuan histologi yang tersering pada kelompok IBD juga dijumpai pada kelompok non-IBD, sehingga diagnosis IBD tidak dapat ditegakkan hanya berdasarkan temuan histopatologi. Pada sebagian besar kasus yang dikirim untuk evaluasi IBD, tidak tersedia data klinis dan temuan endoskopi. Gambaran morfologi yang tumpang tindih dan tidak spesifik serta sediaan yang kurang adekuat turut mempersulit penegakkan diagnosis IBD. Oleh karena itu, pendekatan multidisiplin sangat diperlukan untuk penentuan diagnosis dan terapi IBD yang lebih baik.

Kata kunci: Inflammatory bowel disease, biopsi kolorektal, adekuasi spesimen

\section{INTRODUCTION}

Inflammatory bowel disease (IBD) is a chronic, relapsing disorder that affects patients' quality of life. According to the data from National consensus of IBD Management in Indonesia, among 1,540 patients undergoing colonoscopy in Cipto Mangunkusumo National Referral Hospital from 2017 to 2018, 173 $(11.2 \%)$ were diagnosed as IBD. ${ }^{1}$ Our data from archives of Anatomical Pathology Department, Cipto Mangunkusumo National Referral Hospital Jakarta showed that IBD accounts for $8.8 \%$ of non-neoplastic colorectal biopsy in 2019.

Due to its increasing incidence and its impact, IBD becomes one of the major differential diagnoses which should always be considered when dealing with non-neoplastic colorectal biopsies. While colorectal mucosal biopsies form a great portion of daily workload and mostly are sent for IBD evaluation, pathologist often find difficulties on calling out diagnosis of IBD due to broad spectrum of histologic findings and different stage of disease. Therefore, the availability of clinical data including laboratory findings, endoscopy findings, ancillary studies and histologic assessments is mandatory to establish an accurate diagnosis..$^{2-4}$

This study aims to evaluate the clinical characteristics, endoscopy findings and morphology of biopsy specimens from IBD and non-IBD patients.

\section{METHOD}

This cross-sectional study was done using data registered in the archives of Anatomical Pathology
Department, Cipto Mangunkusumo National Referral Hospital Jakarta. From all 569 cases of non-neoplastic colorectal biopsies in 2019, 50 were identified clinically as IBD. The IBD cases along with other non-neoplastic colorectal biopsy cases were reviewed. One case was excluded due to insufficient specimen. The remaining 49 IBD cases along with 49 cases of non-neoplastic colorectal biopsy acquired by simple random sampling were investigated for specimen adequacy, clinical, endoscopy, and histology findings. The clinical information and endoscopy findings were retrieved from histopathology request forms. The data was analyzed using Statistical Package For The Social Sciences (SPSS) ver 25.0. Chi-square test was performed. For data that did not meet the requirements for the test, Fisher's Exact test served as an alternative. Any obstacle and suboptimal event encountered during histologic evaluation were recorded.

This study including the recording of clinical, endoscopic, and histological data have been approved by The Ethics Committee of the Faculty of Medicine, Universitas Indonesia - Cipto Mangunkusumo Hospital, protocol number 21-04-0359.

\section{RESULTS}

Most samples were adult with a slight female predominance. The working diagnosis was stated in all request forms. However, only 26 (26.5\%) forms contained information about clinical history and only 20 (20.4\%) included endoscopy findings. The clinical characteristics and endoscopy findings were listed in Table 1. 
Table 1. Clinical demographics and endoscopy findings

\begin{tabular}{|c|c|c|c|}
\hline Variable & $\begin{array}{c}\text { IBD } \\
\text { (n = 49) } \\
n(\%)\end{array}$ & $\begin{array}{c}\text { Non-IBD } \\
(n=49) \\
n(\%)\end{array}$ & $\mathbf{P}$ \\
\hline \multicolumn{4}{|l|}{ Age } \\
\hline $0-<18$ years old & $9(18.4)$ & $13(26.5)$ & $0.333^{*}$ \\
\hline$\geq 18$ years old & $40(81.6)$ & $36(73.5)$ & \\
\hline \multicolumn{4}{|l|}{ Gender } \\
\hline Male & 21 (42.9) & 22 (44.9) & $0.839 *$ \\
\hline Female & $28(57.1)$ & $27(55.1)$ & \\
\hline \multicolumn{4}{|l|}{$\begin{array}{l}\text { Information provided in } \\
\text { histopathology request form }\end{array}$} \\
\hline Diagnosis & $49(100.0)$ & 49 (100.0) & \\
\hline Clinical history & $10(20.4)$ & $16(32.7)$ & \\
\hline Endoscopy findings & $13(26.5)$ & $7(14.3)$ & \\
\hline \multicolumn{4}{|l|}{ Sign and symptoms } \\
\hline Gastrointestinal bleeding & $1(10.0)$ & $4(25.0)$ & $0.617 * *$ \\
\hline Chronic diarrhea & $4(40.0)$ & $11(68.8)$ & $0.228 * *$ \\
\hline Abdominal pain & $3(30.0)$ & $2(12.5)$ & $0.340 * *$ \\
\hline Therapy evaluation & $3(30.0)$ & $0(0.0)$ & $0.046 * *$ \\
\hline History of abdominal surgery & $0(0.0)$ & $1(6.3)$ & $1.000 * *$ \\
\hline \multicolumn{4}{|l|}{ Endoscopy findings $(n=13)$} \\
\hline Ulceration & $8(61.5)$ & $1(14.3)$ & $0.070 * *$ \\
\hline Polyp & $4(30.8)$ & $1(14.3)$ & $0.613^{* *}$ \\
\hline Hyperemia & $4(30.8)$ & $2(28.6)$ & $1.000 * *$ \\
\hline Hemorrhoid & $3(23.1)$ & $1(14.3)$ & $1.000 * *$ \\
\hline Colitis/proctitis & $2(15.4)$ & $1(14.3)$ & $1.000 * *$ \\
\hline Inflammatory bowel disease (IBD) & $2(15.4)$ & $0(0.0)$ & $0.521 * *$ \\
\hline Diverticle/diverticulosis & $2(15.4)$ & $2(28.6)$ & $0.587^{* *}$ \\
\hline Edema & $1(7.7)$ & $1(14.3)$ & $1.000 * *$ \\
\hline Skip lesion & $1(7.7)$ & $0(0.0)$ & $1.000 * *$ \\
\hline Stenosis & $1(7.7)$ & $1(14.3)$ & $1.000 * *$ \\
\hline Mucosal erosion & $0(0.0)$ & $1(14.3)$ & $0.350 * *$ \\
\hline
\end{tabular}

IBD: Inflammatory bowel disease

*Pearson Chi-square

**Fisher's Exact test

The most common sign/symptom acquired from the clinical history in both IBD and non-IBD populations was chronic diarrhea. Ulceration was found in $61.5 \%$ of IBD patients, compared to $14.3 \%$ of non-IBD patients. None of the result was statistically significant.

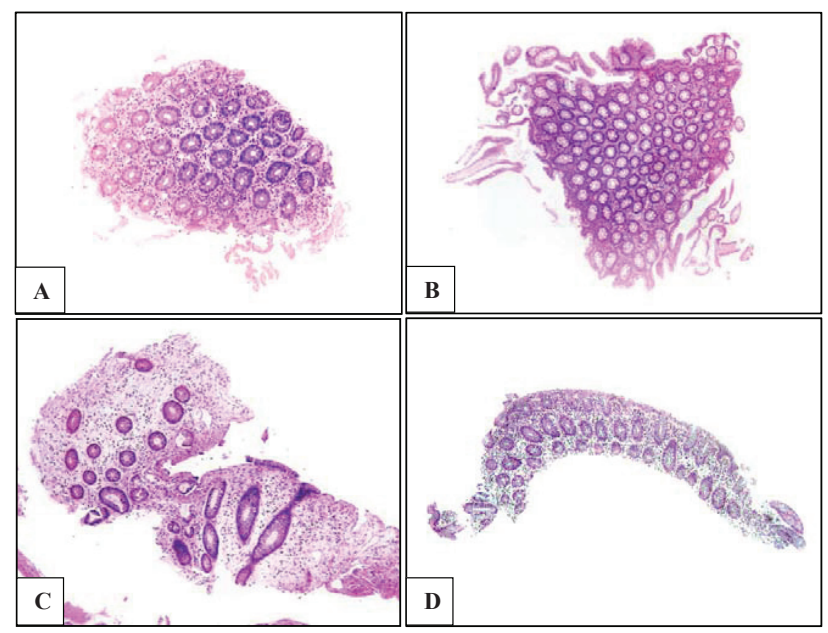

Figure 1. Suboptimal events. (A) Limited specimen (inadequate amount), H\&E $\times 100,(B)$ Incorrect orientation, H\&E ×100, (C,D) Biopsy specimen does not include muscularis mucosae (insufficient depth), H\&E $\times 100, \times 40$

More than half of the specimens (59.2\%) were considered suboptimal for evaluation. Figure 1 and Table 2 explore the difficulties found during histological assessment.
Table 2. Suboptimal events

\begin{tabular}{|c|c|c|c|}
\hline Suboptimal events & $\begin{array}{l}\text { IBD } \\
(n=29) \\
n(\%)\end{array}$ & $\begin{array}{l}\text { Non-IBD } \\
(n=20) \\
n(\%)\end{array}$ & $\begin{array}{l}\text { Total } \\
(n=49) \\
n(\%)\end{array}$ \\
\hline Inadequate amount of specimen & $2(6.9)$ & $3(15.0)$ & $5(10.2)$ \\
\hline Undesignated biopsy site & $5(17.2)$ & $2(10.0)$ & $7(14.3)$ \\
\hline $\begin{array}{l}\text { Mixing tissues from multiple sites into } \\
\text { a single container }\end{array}$ & $22(75.9)$ & $13(65.0)$ & $35(71.4)$ \\
\hline Insufficient specimen depth & $2(6.9)$ & $1(5.0)$ & $3(6.1)$ \\
\hline Incorrect orientation & $2(6.9)$ & $3(15.0)$ & $5(10.2)$ \\
\hline
\end{tabular}

The histologic features suggesting inflammatory processes were recorded and listed in Table 3. Diffuse lymphoplasmacytic infiltration, basal plasmacytosis and basal lymphoid aggregates could not be assessed in some cases due to incorrect specimen orientation. Some specimens were mixed and sent in one container, making it impossible to decide whether the disease involves entire colon segments or not (localized/partial involvement), and whether the presence of Paneth cells was a normal finding or a pathologic feature (hyperplasia and/or metaplasia).

Table 3. Histologic features

\begin{tabular}{|c|c|c|c|}
\hline Histologic features & $\begin{array}{l}\text { IBD } \\
(n=49) \\
n(\%)\end{array}$ & $\begin{array}{l}\text { Non-IBD } \\
(\mathrm{n}=49) \\
\mathrm{n}(\%)\end{array}$ & p \\
\hline Surface erosion/ulceration & $8(16.3)$ & $9(18.4)$ & $0.790^{*}$ \\
\hline Epithelial degeneration/regeneration & $17(34.7)$ & $13(26.5)$ & $0.381^{*}$ \\
\hline Apoptosis & $10(20.4)$ & $6(12.2)$ & $0.274^{*}$ \\
\hline Edema & $2(4.1)$ & $1(2.0)$ & $1.000 * *$ \\
\hline Hemorrhage & $4(8.2)$ & $2(4.1)$ & $0.678 * *$ \\
\hline Necrosis & $7(14.3)$ & $3(6.1)$ & $0.182 *$ \\
\hline \multicolumn{4}{|l|}{ Neutrophil infiltrates } \\
\hline Interstitial & $26(53.1)$ & 23 (46.9) & $0.544^{*}$ \\
\hline Cryptitis & $19(38.8)$ & $19(38.8)$ & $1.000 *$ \\
\hline Crypt abscess & $5(10.2)$ & $4(8.2)$ & $1.000 * *$ \\
\hline Crypt destruction & $1(2.0)$ & $2(4.1)$ & $1.000 * *$ \\
\hline Intraepithelial eosinophil & $9(18.4)$ & $6(12.2)$ & $0.400 *$ \\
\hline $\begin{array}{l}\text { Diffuse lymphoplasmacytic } \\
\text { infiltration }{ }^{+}\end{array}$ & $37(75.5)$ & $39(81.3)$ & $0.493^{*}$ \\
\hline Basal plasmacytosis ${ }^{\dagger}$ & $0(0.0)$ & $0(0.0)$ & $\mathrm{n} / \mathrm{a}$ \\
\hline Basal lymphoid aggregates ${ }^{\dagger}$ & $19(40.4)$ & $25(52.1)$ & $0.255^{*}$ \\
\hline Fibrosis/collagen deposition & $19(38.8)$ & $6(12.2)$ & $0.003^{*}$ \\
\hline Crypt distortion & $32(65.3)$ & $35(71.4)$ & $0.515^{*}$ \\
\hline Crypt atrophy & $11(22.4)$ & $16(32.7)$ & $0.258^{*}$ \\
\hline Paneth hyperplasia† & $0(0.0)$ & $1(2.1)$ & $1.000 * *$ \\
\hline Paneth metaplasia† & $0(0.0)$ & $0(0.0)$ & $\mathrm{n} / \mathrm{a}$ \\
\hline Granuloma & $2(4.1)$ & $0(0.0)$ & $0.495 * *$ \\
\hline
\end{tabular}

The histologic features mostly did not show much difference between the populations. The most common findings were diffuse lymphoplasmacytic infiltration in the lamina propria and crypt distortion. Fibrosis/ collagen deposition was found in $38.8 \%$ of IBD population compared to $12.2 \%$ of non-IBD population, which was statistically significant $(p=0.003)$. None of the specimen showed basal plasmacytosis and Paneth cell metaplasia. The histologic features are shown in Figure 2. 


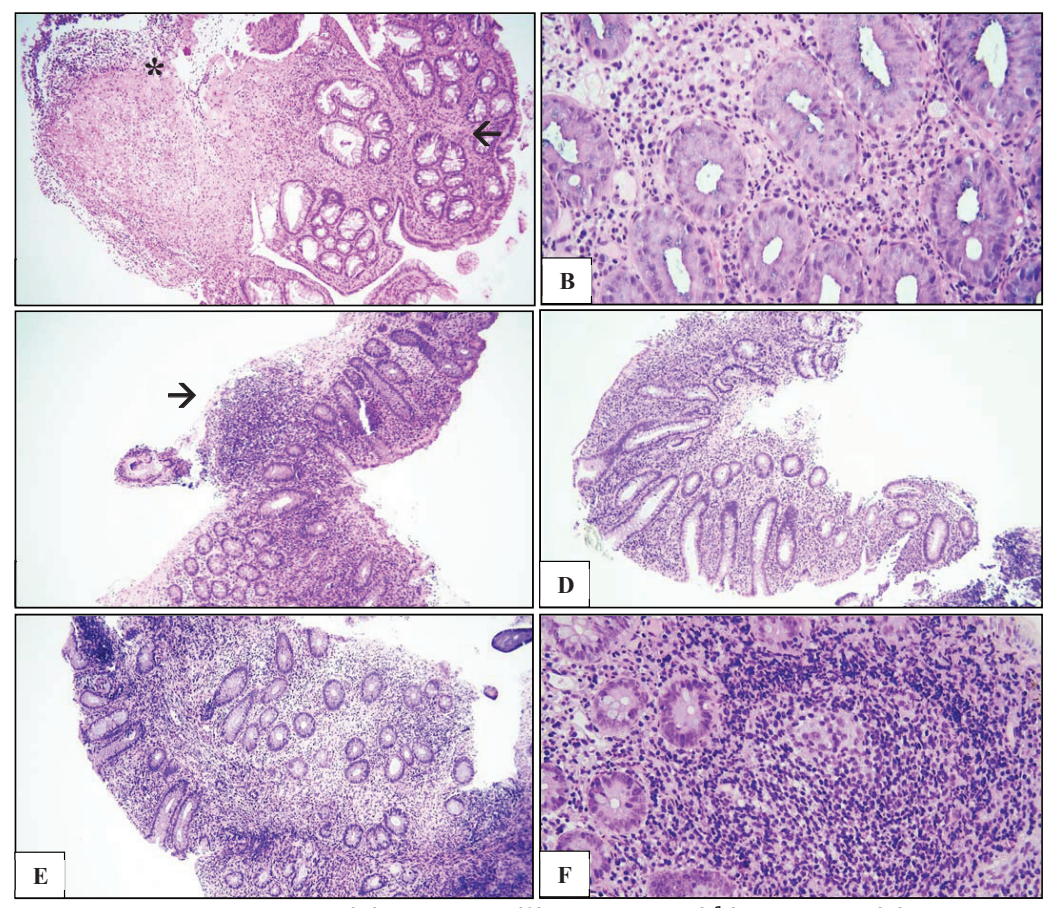

Figure 2. Histologic features: (A) Ulceration $(*)$ and fibrosis $(\leftarrow)$, H\&Ex100; (B) Interstitial neutrophil infiltration, H\&Ex400; (C) Basal lymphoid aggregate $(\rightarrow)$, H\&E $\times 100$; (D) Diffuse lymphoplasmacytic infiltration and crypt distortion, H\&E ×100; (E) Crypt atrophy, H\&E ×100; (F) Granuloma, H\&E $\times 400$

The histologic findings were concluded into 6 categories, most of the cases were signed out as chronic active colitis. There was no significant difference in histologic categories between IBD and non-IBD population.

Table 4. Histologic categories $(n=49)$

\begin{tabular}{lccl}
\hline \multicolumn{1}{c}{ Variable } & IBD & Non-IBD & p value \\
\hline Histologic categories & $\mathbf{n}(\%)$ & $\mathbf{n}(\%)$ & \\
Nonspecific & $10(20.4)$ & $12(24.5)$ & $0.529 *$ \\
Focal active ${ }^{\dagger}$ & $1(2.0)$ & $0(0.0)$ & \\
Chronic inactive & $16(32.7)$ & $13(26.5)$ & \\
Chronic active & $21(42.9)$ & $19(38.8)$ & \\
Infective $^{\dagger}$ & $0(0.0)$ & $5(10.2)$ & \\
Ischemic $^{\dagger}$ & $1(2.0)$ & $0(0.0)$ & \\
\hline
\end{tabular}

†Focal active, infective, and ischemic colitis are reclassified into one variable for the statistic test purpose

*Pearson Chi-square

The activity in IBD population were assessed and categorized as mild, moderate and severe. Finally, most cases $(55.1 \%)$ were diagnosed as active phase IBD (Table 5).

Table 5. Activity grade and final diagnosis in IBD patients $(n=49)$

\begin{tabular}{ll}
\hline Variable & $\mathbf{n}(\%)$ \\
\hline Activity grade & \\
No activity & $22(44.9)$ \\
Mild & $13(26.5)$ \\
Moderate & $8(16.3)$ \\
Severe & $6(12.2)$ \\
Diagnosis ( $=49)$ & \\
IBD (active phase) & $27(55.1)$ \\
IBD (inactive) & $18(36.7)$ \\
IBD (resolving) & $4(8.2)$ \\
\hline
\end{tabular}

The morphology of inflammatory bowel disease cases in various grade of activity is presented in Figure 3.

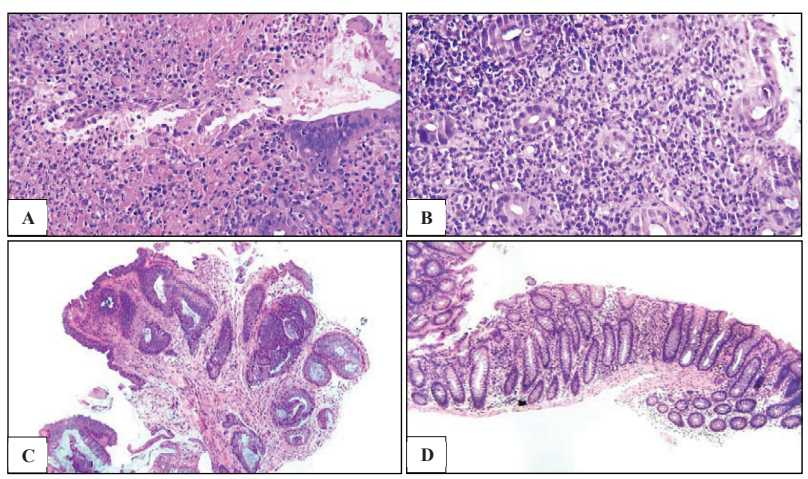

Figure 3. Morphology of inflammatory bowel disease in various grade of activity: (A) active with ulceration, $H \& E \times 100$, (B) active, H\&E×400, (C) inactive, H\&E×100, (D) resolving, H\&E×100.

\section{DISCUSSION}

Inflammatory bowel disease is usually diagnosed in the $3^{\text {rd }}$ and $4^{\text {th }}$ decade with no gender predominance. About $20 \%$ of IBD is diagnosed in children. ${ }^{3}$ In this study, most patients were female adults. Small portions (18.4\%) of the IBD population were children.

To date, many studies have been conducted to improve the diagnosis and management of patients suspected with IBD since it greatly affects patients' quality of life and has a great impact to the society, causing unemployment and psychological problem. However, many cases of IBD remain under- or 
overdiagnosed. The accurate diagnosis of IBD requires comprehensive assessment of clinical data, endoscopy, radiology, laboratory findings and histopathology evaluation. ${ }^{2,5}$ In some conditions, bringing the information together is not easily possible due to limitation of interdisciplinary communication and abundant load of daily cases.

We collect clinical data and endoscopy findings from the histopathology request forms since they serve as the main source of accessible information related to the specimens. From 98 request forms sent, only $26.5 \%$ and $20.4 \%$ contained information regarding the clinical history and endoscopy findings, respectively.

Chronic diarrhea was the most common symptoms stated in the forms. As an unspecific finding, chronic diarrhea can be caused by several different etiologies. It is categorized into watery, fatty, and bloody/ exudative depending on the stool characteristics, each of which has a list of possible etiologies. More detailed information including stool volume, frequency and consistency would be helpful to categorize the diarrhea. Travel history, drug consumptions, physical examinations and laboratory tests are the additional information needed to maximize the diagnostic yield. ${ }^{6-9}$

Diarrhea presented with significant clinical conditions and unspecified etiology is an indication of colonoscopy. Prior to colonoscopy, a bowel preparation procedure is performed to achieve optimal visualization of the bowel mucosa. This preparation procedure should be informed to the pathologist along with the medications used and when it was consumed for it may affect mucosal appearance during endoscopy and histology examination. ${ }^{4,10-13}$

Although being statistically insignificant, this study showed that ulceration was found more frequently in IBD patients. Ulceration can be one of the signs of IBD. However, this finding without further information about its characteristic and clinical history would be considered unspecific. Ulcer can be a complication of bowel preparation and routine medications. The appearance of ulcer including quantity, size and depth can lead to many differential diagnoses. One of the cases was reported to have skip lesion appearance. This finding is highly suggestive of Crohn's disease thus supporting the diagnosis of IBD. ${ }^{5,14,15}$

During histology evaluation, we found some obstacles including insufficient amount and depth of the specimen, unspecified biopsy source and incorrect orientation. Biopsy specimen is considered as representative if taken from four quadrants in the affected and unaffected areas. The specimens should be placed in separate containers according to the biopsy source since the normal morphology differs between each bowel segments. ${ }^{11}$ Failure to obtain biopsy specimens in sufficient amount along with providing information of the designated source and correct orientation will result in limited histology evaluation.

Histology examination is one of the essential modalities in confirming the diagnosis of IBD, assessing the disease activity and extent, excluding other conditions and complications. The histologic features in IBD varied. Morphology of early onset IBD may mimic infective colitis, showing interstitial neutrophil infiltrations, cryptitis, crypt abscess and diffuse lymphoplasmacytic infiltration without crypt distortion. As the disease progresses or being treated, IBD can appear as chronic colitis with crypt architectural disorder, usually without lamina propria fibrosis or hyalinization. Resolving IBD shows a predominantly lymphoplasmacytic inflammation with preserved crypt architecture. ${ }^{4,6,11,16,17}$ Histologic features in both IBD and non-IBD populations in this study mostly showed diffuse lymphoplasmacytic infiltration and crypt distortion, both are the signs of chronic process which can be found in a lot of inflammatory conditions. Fibrosis was more frequently found in IBD population, which is contradictory to some studies. The presence of fibrosis or collagen deposition in our study might indicate coexistent processes that need further elaboration. Fibrosis and lamina propria hyalinization are usually found in chronic ischemic process, radiation injury or mucosal prolapse. Fibrosis may also be found in treated IBD cases. ${ }^{4,6,13,16}$ In this study, only 3 of 49 IBD cases was sent for therapy evaluation, one of them presented with fibrosis. The other 46 cases did not provide information about medication history and biopsy purpose.

The strongest predictor of IBD is the presence of basal plasmacytosis along with crypt distortion. However, the evaluation of this feature requires specific information of biopsy source since basal plasma cells may be found in normal caecum and ascending colon mucosa. ${ }^{16}$ None of the specimens in our study showed basal plasmacytosis. Granuloma is another feature highly suggestive of IBD once the other etiologies have been excluded. ${ }^{4}$ In our study, only 2 of 49 IBD cases showed granuloma formation.

The cases of IBD were further categorized into active phase, chronic and resolving depending on the activity grade. Most of the cases were in the active phase. Without any information about clinical history, previous biopsy result and medications, it is 
not possible to conclude whether this active process is an early active phase or an acute exacerbation of relapsing IBD.

The strength of this study is that we combine clinical data, endoscopy and histopathology findings to reach a more reliable diagnosis. However, this study has two main limitations. Since the data was taken from the request forms, there might be more symptoms and endoscopic findings aside from what were recorded. The second limitation was the lack of uniformity in the number of biopsy specimens taken and inadequacy of the biopsy amount. The standardized biopsy specimens might reveal more specific histologic findings.

\section{CONCLUSION}

The histologic findings in IBD are varied. The most common findings were diffuse lymphoplasmacytic infiltration and crypt distortion, which were also found in non-IBD colitis. Therefore, histopathology alone cannot be used to conclude the diagnosis of IBD. Comprehensive multidisciplinary approach is required for IBD diagnosis. Lack of clinical data and endoscopy findings, overlapping and unspecific morphology as well as suboptimal events during histological evaluation in most cases contribute to the struggles in determining the diagnosis. In addition to more detailed clinical information and ancillary tests, a systematic histological approach is needed to specify the possible differential diagnosis.

\section{REFERENCES}

1. Makmun D, Fauzi A, Maulahela H, Pribadi RR. Konsensus Nasional Penatalaksanaan Inflammatory Bowel Disease di Indonesia. Jakarta: Perhimpunan Gastrointestinal Indonesia; 2019.

2. Chandra S, Simadibrata M. Management of inflammatory bowel disease. Indones J Gastroenterol Hepatol 2014;15:111-4.

3. Hendrickson BA, Gokhale R, Cho JH. Clinical aspects and pathophysiology of inflammatory bowel disease. Clin Microbiol Rev 2002;15:79-94.

4. Moore M, Feakins RM, Lauwers GY. Non-neoplastic colorectal disease biopsies: evaluation and differential diagnosis. J Clin Pathol 2020;73:783-92.

5. Magro F, Langner C, Driessen A, Ensari A, Geboes K, Mantzaris GJ, et al. European consensus on the histopathology of inflammatory bowel disease. J Crohns Colitis 2013;7:827-51.

6. Patil DT, Odze RD. Biopsy diagnosis of colitis: an algorithmic approach. Virchows Arch 2018;472:67-80.

7. Juckett G, Trivedi R. Evaluation of chronic diarrhea. Am Fam Physician 2011;84:1119-26.

8. Schiller LR, Pardi DS, Sellin JH. Chronic diarrhea: diagnosis and management. Clin Gastroenterol Hepatol 2017; 15:182-93.
9. Burgers K, Lindberg B, Bevis ZJ. Chronic diarrhea in adults: evaluation and differential diagnosis. Am Fam Physician 2020;101:472-80.

10. Early DS, Ben-Menachem T, Decker GA, Evans JA, Fanelli RD, Fisher DA, dkk. Appropriate use of GI endoscopy. Gastrointest Endosc 2012;75:1127-31.

11. Abreu MT, Harpaz N. Diagnosis of colitis: making the initial diagnosis. Clin Gastroenterol Hepatol 2007;5:295-301.

12. Lam-Himlin D, Arnold CA, Montgomery EA. Histopathology of iatrogenic injury in the colorectum. Diagnostic Histopathology 2011;17:404-8.

13. Cerilli LA, Greenson JK. The differential diagnosis of colitis in endoscopic biopsy specimens: a review article. Arch Pathol Lab Med 2012;136:854-64.

14. Rameshshanker R, Arebi N. Endoscopy in inflammatory bowel disease when and why. World J Gastrointest Endosc 2012;4:201-11.

15. Lee JM, Lee K-M. Endoscopic diagnosis and differentiation of inflammatory bowel disease. Clin Endosc 2016;49:370-5.

16. Feakins RM. Inflammatory bowel disease biopsies: updated British Society of Gastroenterology reporting guidelines. J Clin Pathol 2013;66:1005-26.

17. Langner C, Magro F, Driessen A, Ensari A, Mantzaris GJ, Villanacci V, et al. The histopathological approach to inflammatory bowel disease: a practice guide. Virchows Arch 2014;464:511-27. 